\title{
РАК ПРИЩИТОПОДІБНОЇ ЗАЛОЗИ У ПІДЛІТКА З КРИТИЧНИМ СИСТЕМНИМ ОСТЕОПОРОЗОМ
}

\author{
Товкай О. А., Паламарчук В. О., Мазур О. В., \\ Войтенко В. В., Зелінська Н. Б., Глоба С. В. \\ Украӥнський науково-практичний иентр ендокринної хірургї, \\ трансплантацї̈ ендокринних органів і тканин при МОЗ України, м. Київ \\ paldoc@i.ua
}

Гіперпаратиреоз (ГПТ) у дітей може бути наслідком доброякісних чи злоякісних гормонально-активних пухлин прищитоподібних залоз (ПщЗ), їх гіперплазії, дефіциту вітаміну D, вітамін D-залежного рахіту, хронічної гіперфосфатемії, хронічної хвороби нирок, у тому числі після їх трансплантації, а у немовлят - проявом компенсаторної реакції на гіпопаратиреоз чи дефіцит вітаміну D у матері.

Первинний гіперпаратиреоз (ПГПТ) е захворюванням, в основі якого лежить первинна гіперфункція ПЩЗ із патологічним надмірним синтезом паратгормону (ПТГ) i, як наслідок, з порушенням обміну кальцію (Са) в організмі $[1,2]$ Поширеність ПГПТ складае в середньому від 1 до 4 випадків на 1000 населення, і частіше зустрічаеться у жінок - 3:1 [3]. Поширеність ПГПТ у дітей є значно меншою, ніж у дорослих в межах 2-5 випадків на 100000 дитячого населення, з вищою частотою серед підліт- ків, а орієнтовна захворюваність серед дітей може складати 1:200.000-300.000 дитячого населення [4].

У підлітків і молодих дорослих основною причиною ПГПТ е спорадичні аденоми ПЩЗ, значно рідше ПГПТ є компонентом одного зі спадкових синдромів множинної ендокринної неоплазії: МЕН1 (внаслідок мутації в гені MEN1), МЕН2А (мутації в $R E T$ протоонкогені на 10 хромосомі), $\mathrm{MEH} 4$ (внаслідок гетерозиготних інактивуючих мутацій в гені $C D K N 2 B$ (12p13.1-p12), що кодуе протеїн р27) [5]. Також ПГПТ може бути компонентом синдрому гіперпаратиреозу пухлини щелепи (Hyperparathyroidism-jaw tumor syndrome, HPT-JT), що спричинений мутаціею гена CDC73 (інша назва - HRPT2), при якому описані як доброякісні, так і злоякісні пухлини однієї чи кількох ПщЗ $[6,7,8]$. У дітей найменшого віку ПГПТ частіше розвивається внаслідок гермінативних гомозиготних інактивуючих мутацій

* Роботу виконано в Українському науково-практичному центрі ендокринної хірургії, трансплантації ендокринних органів і тканин при МОЗ України.

Установою, що фінансуе дослідження, є МОЗ України.

Автори гарантують повну відповідальність за все, що опубліковано в статті.

Автори гарантують відсутність конфлікту інтересів і власної фінансової зацікавленості при виконанні роботи та написанні статті.

Рукопис надійшов до редакції 15.01.2021. 
гена $C A S R$, що кодує Са- чутливий рецептор, розташований на паратиреоцитах. Біалельні мутації цього гена призводять до тяжкого неонатального ГПТ і гіперкальціємії небезпечної для життя немовляти. У більш старшому віці у дітей гетерозиготні інактивуючі мутації гена $C A S R$ частіше мають сприятливіший перебіг ПГПТ і проявляються доброякісною сімейною гіпокальціуричною гіперкальціємією [9].

Основними проявами ПГПТ є біль у кістках, їх деформація, патологічні переломи, біль в суглобах, в животі (гіпоацидність), диспепсичні симптоми, біль в проекції нирок (за розвитку нирково-кам'яної хвороби), поліурія, полідипсія, швидка стомлюваність, слабкість у м'язах, діарея, закрепи, зниження ваги, затримка росту, брадикардія, гіпотензія, тощо. У випадках, коли ПГПТ є складовою частиною одного 3 синдромів (MEH1, MEH2A, MEH4, НРТ-JT тощо), спектр інших клінічних проявів залежить від певної поєднаної патології. Біохімічними критеріями ПГПТ є гіперкальціємія, гіпофросфратемія, гіперкальціурія (хоча $\mathrm{Ca}$ в сечі може бути низьким у разі поєднання $з$ дефіцитом вітаміну D), високий чи неадекватно нормальний рівень в сироватці крові інтактного ПТГ (при високому чи високо-нормальному рівні Са в сироватці). Причинами підвищення рівня Са та ПТГ, можуть бути не лише доброякісні утворення прищитоподібних залоз, але саме у разі раку ПЩЗ (РПЩЗ) ГПТ має більш агресивний перебіг.

В статті наведено клінічний випадок агресивного перебігу РПЩЗ у підлітка з остеопорозом кісток на тлі ПГПт.

\section{Опис клінічного випадку.}

Хлопчик віком 16 років звернувся самостійно на консультацію до Українського науково-практичного центру ендокринної хірургії, трансплантації ендокринних органів і тканини МОЗ України (Центру) з приводу патології кісток, остеопорозу, постійного болю в нижніх кінцівках, в кульшових суглобах спастичного характеру, що не усувається знеболювальними препаратами, неможливості самостійно пересуватись без милиць, підвищеного нічного діурезу, скутос- ті у литкових м'язах. 3 анамнезу відомо, що батьки пацієнта три роки тому звернулися до ортопеда після спонтанного перелому правої великогомілкової кістки у хлопчика. При подальшому спостереженні ортопедом через рік дитині було встановлено діагноз: «Юнацький епіфізеоліз обох кульшових суглобів», зі значним остеопорозом, обмеженням самостійного пересування і в 2019 році виконано остеосинтез обох стегнових кісток (рис. 1). Протягом останнього року показники ПТГ постійно перевищували верхню межу норми більше ніж втричі (максимально - 2171 пг/мл (норма 15-65)), з постійною гіперкальціємією.

При обстеженні в Центрі: зріст 163,6 см (- 1,48 SD), маса тіла, статевий розвиток, стан серцево-судинної системи для віку і статі в нормі. Візуально - значна деформація нижніх кінцівок, пальпаторно в ділянці нижньої щелепи зліва - щільне утворення розміром до 2 см. Лабораторні обстеження: загальний аналіз крові, сечі, сечовина, креатинін, загальний білок на доопераційному та післяопераційному етапах - в межах норми, Са іонізований $\left(\mathrm{Ca}^{++}\right)-1,9$ ммоль/л, Са загальний 3,08 ммоль/л, фросфрор - 0,52 ммоль/л, ПТГ - 1523,2 пг/мл (норма 15-65), 25(OH) вітамін D - 14,32 нг/мл (норма 30-100), ТТГ - 5,69 мкМО/мл (норма 0,27-4,2) вільний $\mathrm{T}_{4}-0,59$ нг/дл (норма 1,1-1,8). ЕКГ, рентгенографія грудної клітини в нормі.

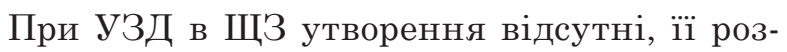
міри в нормі; в проєкції яремної вирізки, частково загрудинно розташоване м'якотканинне утворення зниженої ехогенності, гіперваскулярне в режимі ЦДК $35 \times 13$ мм; зліва в проекції ПЩЗ - гіпоехогенне утворення $9 \times 6$ мм, в проєкції нижньої щелепи зліва - гранульома неправильної форми 16×4 мм. На МСКТ ПЩЗ із контрастуванням в ділянці нижнього полюса лівої частки ЩЗ визначається кістозний утвір округлої форми (ПЩЗ). В ділянці нижнього полюса правої частки ЩЗ - гіперваскулярне утворення округлої форми, з нерівними чіткими контурами, розмірами $21 \times 17 \times 31$ мм, неоднорідної структури за рахунок гіподенсивних включень, що відповідає зміненій правій нижній ПЩЗ. Шийна частка вилоч- 


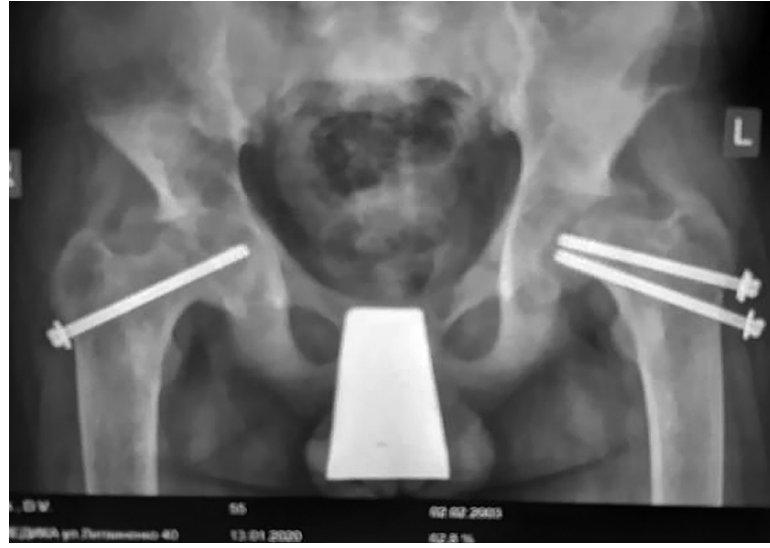

а) рентгенографрія кульшових суглобів

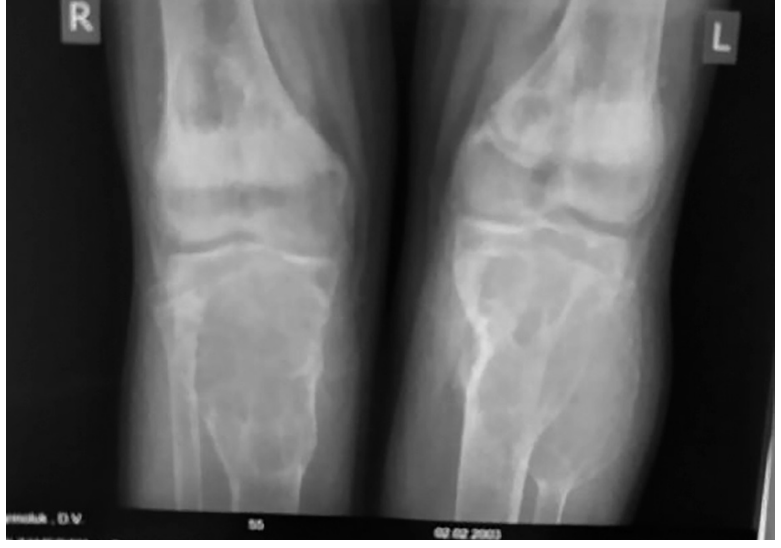

б) рентгенографія колінних суглобів

Рис. 1. Рентгенографія кульшових і колінних суглобів (цифрова рентгенологічна система Philips Bucky Diagnost):

ознаки епіфізеолізу голівок обох стегнових кісток, двобічного коксартрозу, відносне вкорочення лівої ноги. Ознаки системного ураження кісток за типом фіброзної дисплазії.

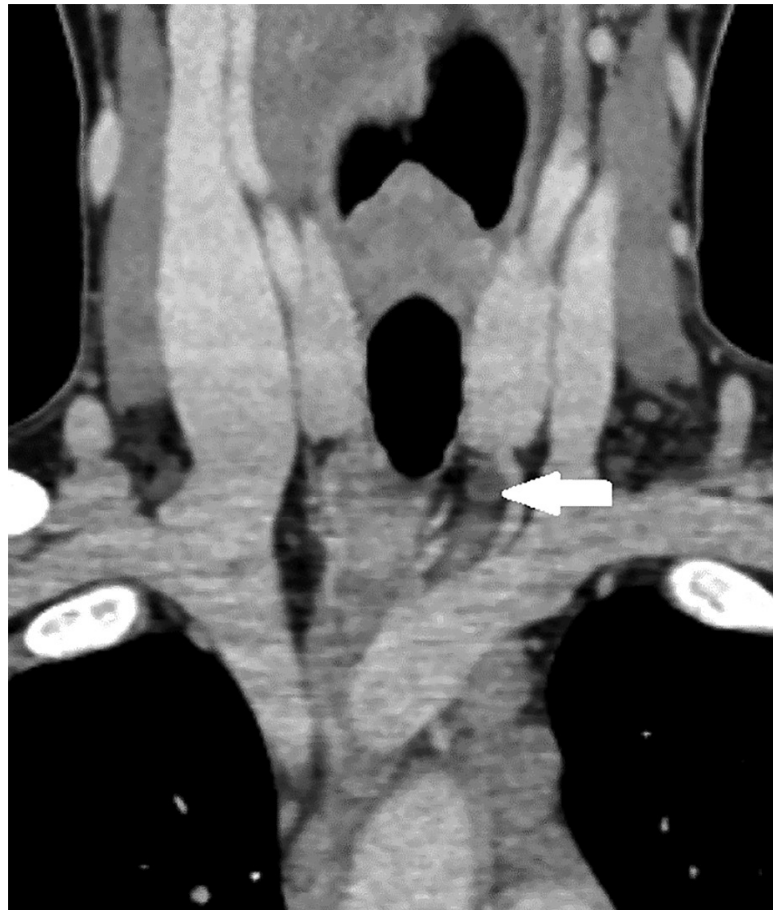

Біла стрілка — кіста лівої нижньої ПщЗ

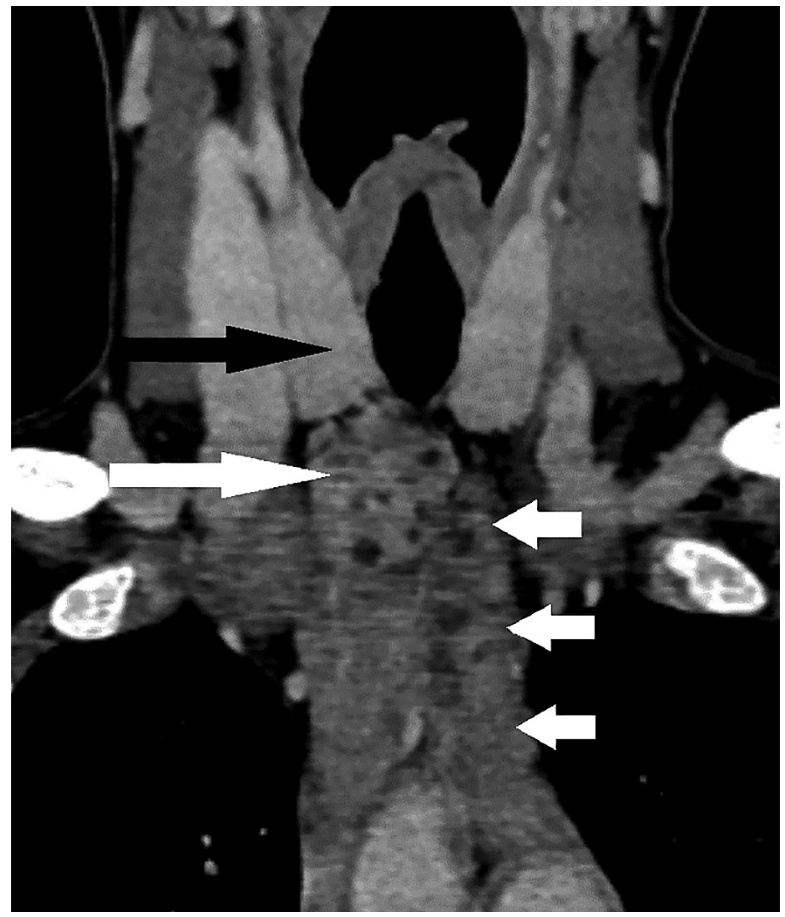

Довга біла стрілка - змінена права нижня ПЩЗ. Чорна стрілка - права частка щитоподібної залози. Білі короткі стрілки гіподенсивні включення шийної частки тимусу

Рис. 2. МСКТ ПщЗ із контрастуванням (Toshiba Aquilion)

кової залози зліва, неоднорідної структури за рахунок гіподенсивних включень (Рис. 2).

За результатами лабораторного та інструментального обстеження встановлено діагноз: ПГПТ, маніфестна кісткова фрорма, важкий перебіг. Аденома правої нижньої ПЩЗ. Кіста лівої нижньої ПЩЗ. Бура пухлина нижньої щелепи. Остеодистрофія верхньої третини обох гомілок. Стан після остеосинтезу стегнових кісток (2019 рік). Первинний гіпотиреоз. Затримка зросту соматогенна. Пухлина тимусу?

Хворого доправлено до хірургічного відділення для проведення оперативного лікування та виконано оперативне втручання в об'ємі: ревізія ПЩЗ для виявлен- 


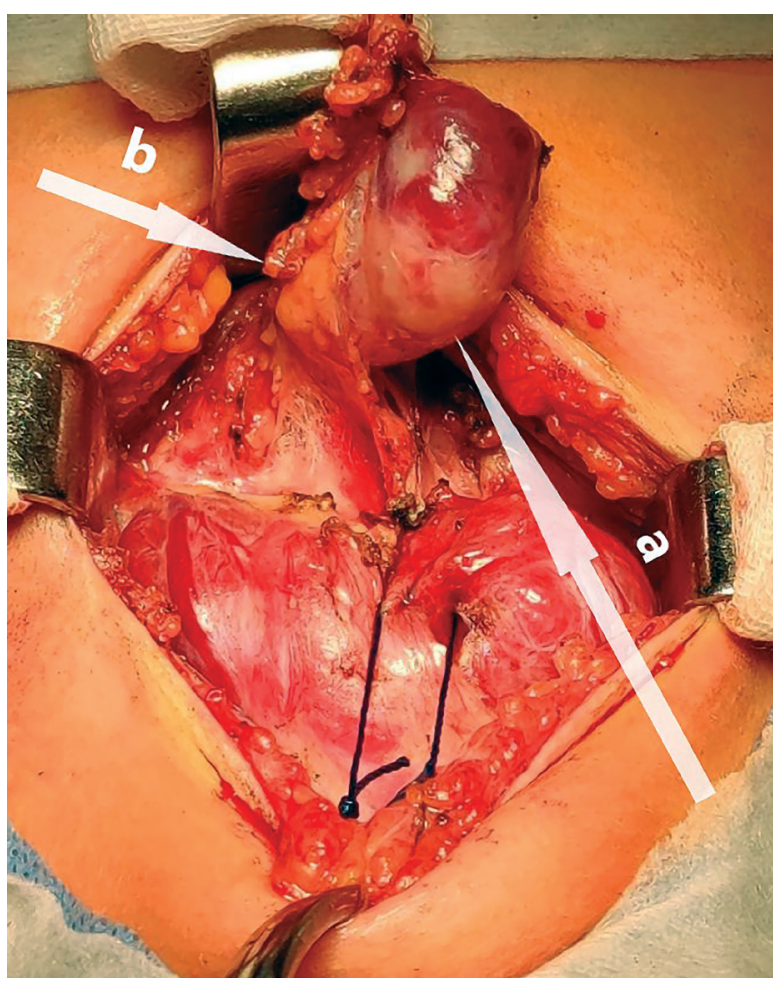

Рис. 3. Операційне поле.

Стрілки: а — пухлина правої нижньої ПЩЗ; $\mathrm{b}$ - верхній ріг тимусу

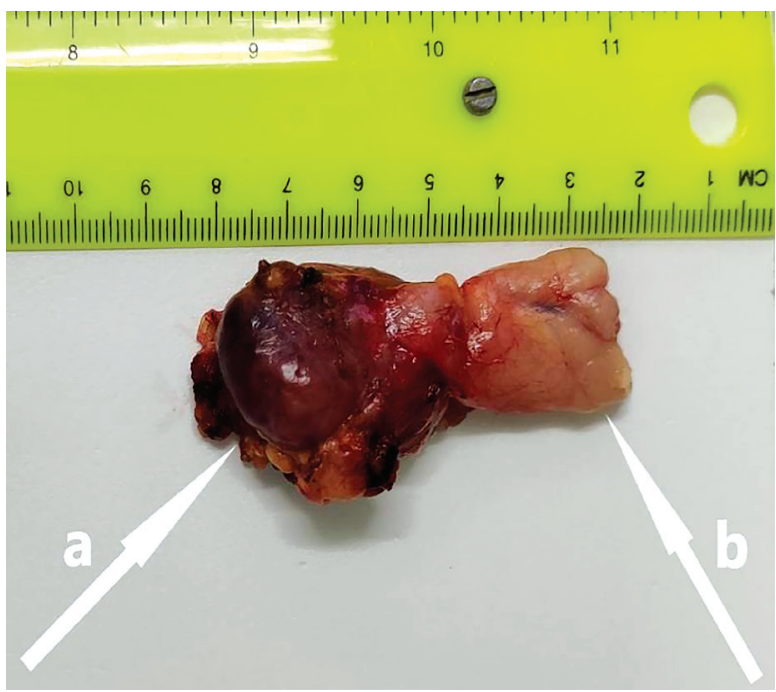

Рис. 4. Видалена пухлина правої нижньої ПЩЗ на планшетці для оцінки розмірів (стрілка а — пухлина ПЩЗ; b - фррагмент тимусу)

ня їх гіперплазії та пухлинних утворень, видалення пухлини правої та лівої нижньої ПЩЗ з резекцією рогу тимусу. Під час оперативного втручання виявлено пухлинне утворення, що знаходилось в межах правого рогу тимусу, на 4 см нижче нижнього полюса правої частки ШЗ, розмірами
$30 \times 22 \times 15$ мм, загальною вагою до 4,3 грамів (рис. 3,4$)$. Експрес-гістологічний висновок: пухлина правої ПЩЗ, що містить цитологічні елементи, характерні для РПЩЗ. Фрагмент тканини тимусу без змін гістологічної будови.

Під час операції, одразу після видалення пухлини ПЩЗ, виконано забір крові, що вказав на нормалізацію показників ПТГ і Са: ПТГ - 12,8 пг/мл, $\mathrm{Ca}^{++}$1,34 ммоль/л. В динаміці, через 4 дні після оперативного втручання рівень ПТГ становив 59,6 пг/мл, $\mathrm{Ca}^{++}-1,28$ ммоль/л.

\section{При патогістологічному досліджен-} ні пухлина ПЩЗ має солідну будову і складається 3 основних клітин ПЩЗ. Жирова тканина в стромі пухлини відсутня. В стромі визначаються фіброз і кістозна дегенерація. Пухлина оточена фіброзною капсулою. Визначаються ознаки інвазї в капсулу пухлини, а також ознаки екстраорганної інвазії в жирову тканину. В жировій клітковині визначається тканина тимуса без гістологічних особливостей будови (рис. 5)

Остаточний діагноз: Рак правої нижньої Пщ3 T2N0Mx (8-ма редакція, 2017 рік), I стадія, III клінічна група. Кіста лівої нижньої ПщЗ. Бура пухлина нижньої щелепи. Епіфізеоліз головок обох стегнових кісток. Остеодистрофія верхньої третини обох гомілок. Стан після остеосинтезу стегнових кісток (2019 рік). Первинний гіпотиреоз. Затримка зросту соматогенна.

Для з'ясування можливої генетичної причини ГПТ хворому було проведене до-

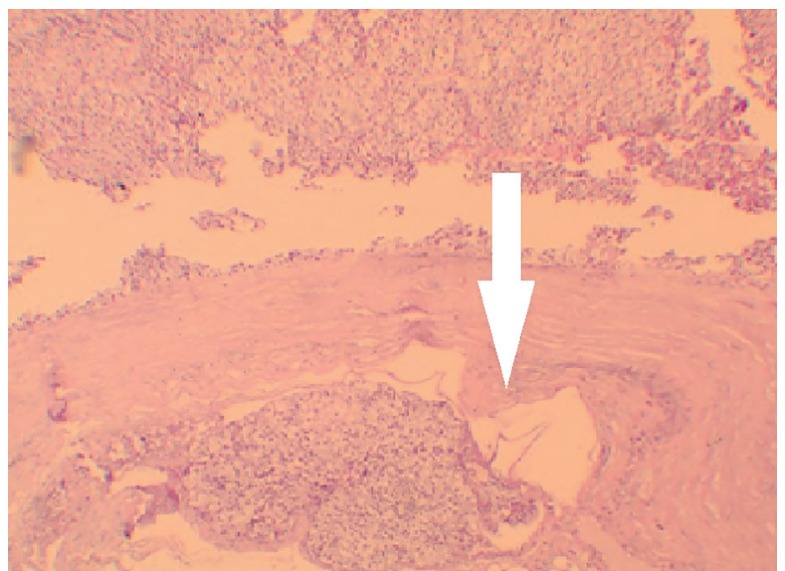

Рис. 5. Білою стрілкою вказано ознаки екстраорганної інвазії в жирову клітковину 


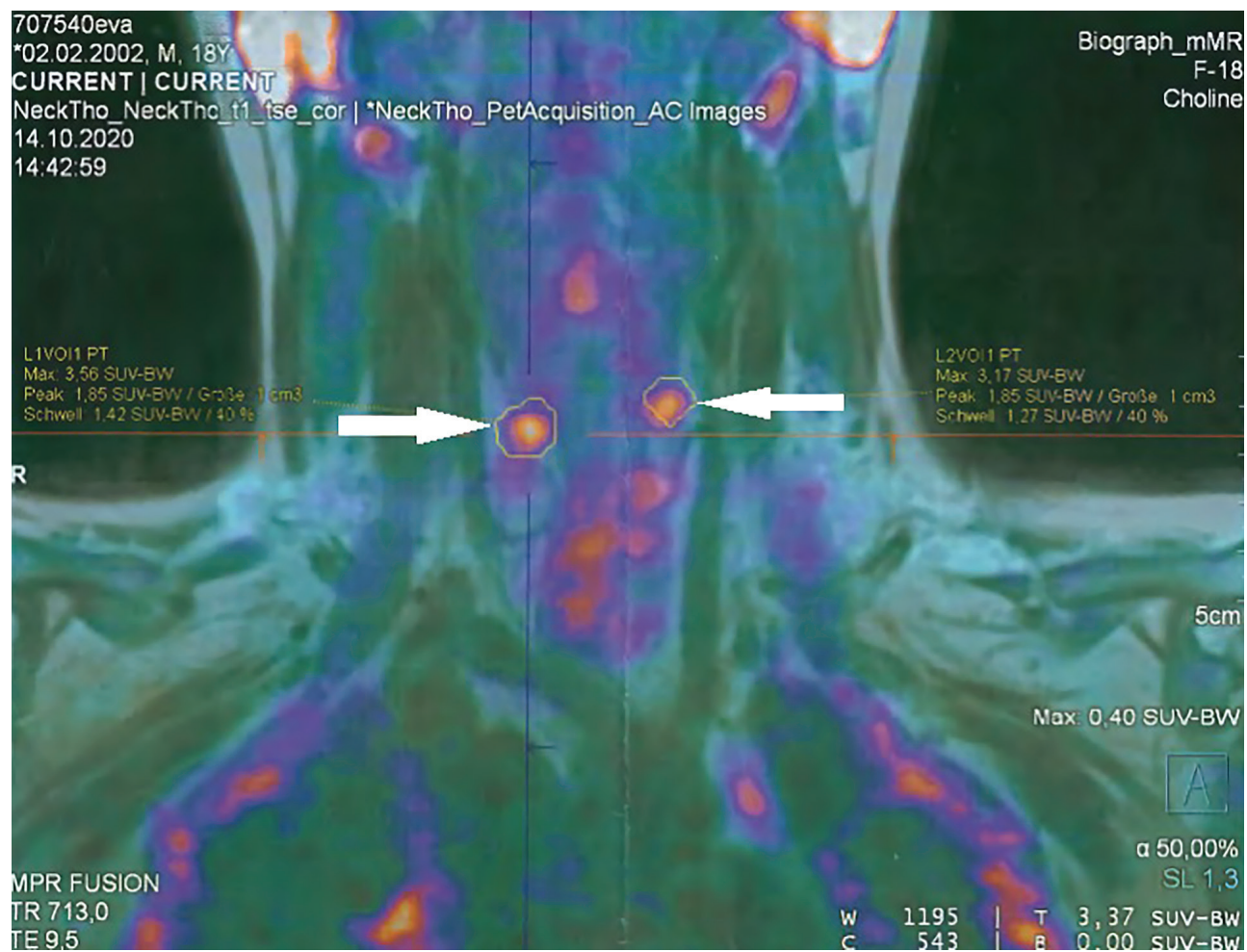

Рис. 6. Білою стрілкою вказані вогнища накопичення фармпрепарату

слідження в генетичній лабораторії США за допомогою таргетної multicancer панелі (з аналізом понад 80 генів, зокрема генів $\mathrm{MEH).} \mathrm{Виявлена} \mathrm{мутація} \mathrm{МАX} \mathrm{с.25G} \mathrm{>} \mathrm{T}$ (p.Val9Leu), що була класифікована як неясно значуща (VUS). Мутації в гені MAX асоційовані з розвитком спадкової феохромоцитоми-парагангліоми, але не були описані у паціентів з ізольованим ПГПТ $[10,11]$.

Після оперативного лікування паціент перебував під динамічним наглядом дитячого ендокринолога Центру з контролем показників $\mathrm{Ca}^{++}$, ПТГ, 25(OH) вітаміну D в сироватці крові, з проведенням корекції лікування залежно від їх рівнів препаратами Са й вітаміну D. На тлі терапії з часом стан хворого клінічно поліпшився, біль в нижніх кінцівках припинився, через 6 міс. хлопчик зміг самостійно пересуватись без милиць, розміри кісти нижньої щелепи зменшились до 1 см. Разом із тим, через 2 місяці після операції рівень ПТГ став поступово зростати (до 152 пг/мл), з помірним зниженням рівня вітаміну D на тлі нормально-високих показників $\mathrm{Ca}^{++}$в крові. Це вимагало збільшення дози препаратів вітаміну D і зміни його виду. Корекція підвищеного рівня ПТГ проводилась препаратами альфакальцидолу чи кальцитріолу як у вигляді монотерапії, так і у поєднанні з холекальциферолом. Зважуючи високі показники ПТГ з метою уточнення ймовірності персистенції захворювання, паціенту було виконано ПЕТ/КТ (з 11С-холіном) (рис. 6).

Було виявлено накопичення радіофармпрепарату в проекції правої та лівої верхніх ПЩЗ, розмірами 6 і 5 мм відповідно, без накопичення препарату в проекції видаленої злоякісної пухлини ПЩЗ (відсутність персистенції пухлини)

\section{ОБГОВОРЕННЯ}

РПЩЖ - це рідкісне злоякісне захворювання, що виникає спорадично або є проявом певних генетичних мутацій. Поширеність РПЩЖ серед хворих на ПГПТ не перевищуе $1 \%$, однак частота варіюе в різних країнах: зокрема, від 1\% пацієнтів з ПГПТ в США до $5 \%$ і $5,2 \%$ в Японії і Італії відповідно [12]. РПЩЖ серед дітей е вкрай рідкісним, як в спорадичних випадках, так і у випадках сімейного ГПТ [11]. 5- і 10-річна 
виживаність пацієнтів з РПЩЖ становить 78-85\% і 49-70\% відповідно [13], при цьому рецидив хвороби зустрічається у більш ніж 50\% пацієнтів [14]. Метастазування в лімфратичні вузли зустрічається дуже зрідка, і летальність є наслідком метастатичного ураження внутрішніх органів [15]. Етіологія РПЩЖ, як і інших злоякісних новоутворень, ймовірно, пов'язана з взаємодією безлічі екологічних і генетичних факторів. Вплив радіації, особливо в дитинстві, збільшує ризик доброякісного захворювання ПЩЗ, а також одночасної неоплазії щитовидної залози і ПщЗ, але неясно, чи є такий вплив етіологічним фактором РПЩЖ. Основну роль в патогенезі як спорадичного, так і сімейного типу РПЩЖ відіграє вроджена мутація гена-супресора CDC73, який кодуеться геном HRPT2 і розташовується на 1q2,5 хромосомі. Останні дослідження вказують, що саме соматичні мутації гена CDC73 присутні в 66-100\% випадків спорадичного РПЩЖ, в той час як в спорадичних доброякісних аденомах ПЩЗ спостерігаються в 1\% випадків [16]. Молекулярний патогенез РПЩЖ залишається досі слабо вивче- ним, оскільки незмінені клітини ПЩЗ мають знижений клітинний обмін, що значно ускладнює вивчення генетичних і обмінних особливостей малігнізованих клітин. Однак, дослідження, проведені FernandezRanvier et al. [17], продемонстрували збільшення швидкості обміну речовин і генетичних змін в ракових клітинах в порівнянні з клітинами доброякісних пухлин ПЩЗ.

Клінічна картина РПЩЗ різноманітна, не містить жодного патогномонічного симптому, має перебіг під маскою різних захворювань. Жодне лабораторне дослідження не дає можливості діагностувати РПЩЖ, але деякі результати дозволяють запідозрити РПЩЖ при виявленні у пацієнта ПГПТ. Так, середні значення загального Са в сироватці крові у пацієнтів з РПЩЖ, згідно 3 даними досліджень за останні три десятиліття, складають 14,6 мг/дл (3,5 ммоль/л), і близько 60-65\% пацієнтів мають рівень Са понад 14,6 мг/дл (> 3,5 ммоль/л) [18]. Ідентифікація нових лабораторних маркерів, які можуть допомогти диференціювати злоякісні варіанти ПГПТ від доброякісних, $є$ постійним предметом досліджень.

\section{ВИСНОВОК}

1. Даний клінічний випадок свідчить про складність диференційної діагностики РПЩЗ у пацієнта з ПГПТ у зв'язку з відсутністю патогномонічної симптоматики та специфрічних діагностичних маркерів.

2. Незважаючи на низьку частоту РПЩЗ, зокрема у дітей, необхідно детально аналізувати кожен випадок ПГПТ з огляду на можливість злоякісного процесу в ПЩЗ, надто при значно високих рівнях ПТГ, $\mathrm{Ca}^{++}$крові та тяжкої клінічної симптоматики ГПТ.

3. Своєчасна верифікація злоякісної пухлини ПщЗ дає можливість вчасної діагно- стики i, відповідно, визначення тактики та адекватного об'єму оперативного втручання.

4. Дітям з патологією кісткової системи, що проявляється патологічними переломами, епіфізеолізом, остеопенією чи остеопорозом, зокрема з гіперкальціємією, слід проводити обстеження на патологію ПщЗ для вчасного лікування і уникнення інвалідизуючих тяжких ускладнень хвороби.

5. Підвищення рівня ПТГ крові після оперативного втручання на ПЩЗ може свідчити не лише про персистенцію хвороби, а й про їх гіперплазію.

\section{ЛITEPATУРA \\ (REFERENCES)}

1. Bilezikian JP. Primary Hyperparathyroidism. In: Feingold KR, Anawalt B, Boyce A, et al., Endotext, South Dartmouth, 2000, available at: https://www.ncbi.nlm. nih.gov/books/NBK278923.

2. Palamarchuk VA, Tovkaj AA, Vojtenko VV, et al. Klinichna endokrynologija ta endokrynna hirurgija 2019; 1: 7-17. doi: http://doi.org/10.30978/CEES-2019-1-7.
3. Heath DA. Endocrinol Metab Clin North Am 1989; 18: 631-646.

4. Mallet E. Horm Res 2008; 69(3): 180-188.

5. Nicholson KJ, McCoy KL, Witchel SF, et al. Surgery 2016; 160(4): 1008-1016.

6. Starker LF, Akerström T, Long WD, et al. Horm Cancer 2012; 3(1-2): 44-51. 
7. Thakker RV. J Intern Med 2016; 280(6): 574-583. doi: 10.1111/joim.12523.

8. Hyperparathyroidism-jaw tumor syndrome, available at: https://ghr.nlm.nih.gov/condition/hyperparathyroidism-jaw-tumor-syndrome\# synonyms.

9. Roizen J, Levine MA. J Chin Med Assoc 2012; 75(9): 425-434. doi:10.1016/j.jcma.2012.06.012.

10. Messerer CL, Bugis SP, Baliski C, Wiseman SM. World J Surg Oncol 2006; 4: 10. doi:10.1186/1477-7819-4-10.

11. Comino-Méndez I, Gracia-Aznárez FJ, Schiavi F, et al. Nat Genet 2011; 43(7): 663-667.

12. Lumachi F, Basso SMM, Basso U. Anticancer Res 2006; 26: 4803-4808.
13. Harari A, Waring A, Fernandez-Ranvier G, et al. J Clin Endocrinol Metab 2011; 96(12): 3679-3686. doi: 10.1210/ jc.2011-1571.

14. Lee PK, Jarosek SL, Virnig BA, et al. Cancer 2007; 109(9): 1736-1741. doi: 10.1002/cncr.22599.

15. Sadler C, Gow KW, Beierle EA, et al. Surgery 2014; 156(6): 1622-1629. doi: 10.1016/j.surg.2014.08.069.

16. Sharretts JM, Kebebew E, Simonds WF. Semin Oncol 2010; 37(6): 580-590. doi: 10.1053/j.seminoncol.2010.10.013.

17. Fernandez-Ranvier GG, et al. Cancer 2009; 115(2): 334344. doi: 10.1002/cncr.24037.

18. Carole Guerin, Pauline Romanet, David Taieb, et al. Endocr Relat Cancer 2018; 25(2): T15-T28. doi:10.1530/ ERC-17-0266.

\section{РАК ПРИЩИТОПОДІБНОІ ЗАЛОЗИ У ПІДЛІТКА З КРИТИЧНИМ СИСТЕМНИМ ОСТЕОПОРОЗОМ}

Товкай О. А., Паламарчук В. О., Мазур О. В., Войтенко В. В., Зелінська Н. Б., Глоба С. В.

Український науково-практичний иентр ендокринної хірургї̈, трансплантаиї ендокринних органів і тканин при МОЗ України, м. Київ paldoc@i.ua

Не зважаючи на низьку частоту раку прищитоподібної залози (РПщЗ) у дітей, кожен випадок первинного гіперпаратиреозу (ПГПТ) повинен детально аналізуватись з огляду на можливість наявності злоякісного процесу, особливо при надто високих рівнях Паратгормону (ПТГ) та Кальцію іонізованного (Ca++) крові у поєднанні з важкою симптоматикою, що частіше проявляеться у вигляді системного остеопорозу та переломами трубчастих кісток, вираженим утворенням конкрементів в нирках та жовчному міхурі.

Біохімічними критеріями ПГПТ, як при доброякісних утвореннях ПЩЗ, так і при злоякісних, окрім підвищення рівня ПТГ та гіперкальціємії, являються: гіпофоссратемія, гіперкальціурія (хоча Са в сечі може бути низьким у разі поєднання з дефіцитом вітаміну D). Для з'ясування генетичної причини гіперпаратиреозу можливе проведення генетичного дослідження із використанням таргетної multicancer панелі (з аналізом понад 80 генів, зокрема генів МЕН). Уданому випадку виявлена мутація MAX c.25G > T (p.Val9Leu), що була класифікована як неясно значуща (VUS). Мутації в гені MAX асоційовані з розвитком спадкової феохромоцитоми-парагангліоми, але не були описані у пацієнтів з ізольованим ПГПТ, що підтверджуе відсутність зв’язку генетичного аспекту та наявної пухлини ПЩЗ.

Методом лікування РПЩЗ, я одніеї з причин ПГПТ - оперативне, з наступним динамічним наглядом та контролем показників ПТГ та Са++ плазми крові у поєднанні з візуалізаційними методами дослідження. Підвищення рівня останніх вище референтних показників в післяопераційному періоді, у даному випадку ПТГ - 152 пг/мл, що коригуеться препаратами альфакальцидолу чи кальцитріолу як у вигляді монотерапії, так і у поєднанні з холекальциферолом, відсутністю топічної візуалізації, не завжди вказують на персистенцію хвороби.

В таких випадках, додатковим методом діагностики можливої персистенції захворювання, може слугувати ПЕТ/КТ (з 11С-холіном), який дозволяе диференціювати накопичення фрармпрепарату в нетипових місцях проведеної операції.

К лючові слова: рак прищитоподібної залози, хірургічне лікування, первинний гіперпаратиреоз, діагностика. 


\section{THYROID CANCER IN AN ADOLESCENT WITH CRITICAL SYSTEMIC OSTEOPOROSIS}

Tovkai O. A, Palamarchuk V. O, Mazur O. V., Voitenko V. V., Zelinska N. B., Globa E. V.

Ukrainian scientific and practical center of endocrine surgery, transplantation of endocrine organs and tissues of MoH of Ukraine, Kyiv paldoc@i.ua

Despite the low incidence of thyroid cancer (PCOS) in children, each case of primary hyperparathyroidism should be analyzed in detail for the presence of a malignant process, especially at too high levels of parathyroid hormone $(\mathrm{PTH})$ and calcium ionized $\left(\mathrm{Ca}^{++}\right)$blood. in combination with severe symptoms, which are more often manifested in the form of systemic osteoporosis and fractures of the tubular bones, expressed by the formation of stones in the kidneys and gallbladder.

Biochemical measures for primary hyperparathyroidism, both in benign and malignant parathyroid tumors, in addition to elevated PTH and hypercalcemia, are: hypophosphatemia, hypercalciuria (although Ca in the urine may be low in combination with vitamin $\mathrm{D}$ deficiency). To determine the genetic cause of hyperparathyroidism, it is possible to perform a genetic research using a target multicancer panel (with analysis of more than 80 genes, including MEN genes). In this case, a mutation of MAX c.25G> T (p.Val9Leu) was detected, which was classified as unclearly significant (VUS). Mutations in the MAX gene have been associated with the development of hereditary pheochromocytoma-paraganglioma, but have not been described in patients with isolated primary hyperparathyroidism, confirming the lack of association between the genetic aspect and the existing parathyroid tumor.

One of the causes of parathyroid cancer is operative, with the subsequent dynamic supervision and control of indicators of PTH and $\mathrm{Ca}^{++}$of blood plasma in combination with imaging methods of research. Increase in the level of the last above reference values in the postoperative period, in this case PTH - $152 \mathrm{pg} / \mathrm{ml}$, which is corrected by alfacalcidol or calcitriol both as monotherapy and in combination with cholecalciferol, lack of topical imaging, do not always indicate persistent disease.

In such cases, an additional method of diagnosing the possible persistence of the disease may be PET/CT (with 11C-choline), which allows to differentiate the accumulation of the drug in atypical sites of the surgical operation.

Key words: thyroid cancer, surgical treatment, primary hyperparathyroidism, diagnosis. 